\title{
Crescent-shaped extensive pericardial calcification
}

\author{
Tom Devasia, Hashir Kareem, Rajaram Prasad, Abdul Razak
}

Department of Cardiology, Kasturba Medical College, Manipal, Karnataka, India

\section{Correspondence to}

Dr Rajaram Prasad, prasad.asaithambi@gmail.com

Accepted 5 July 2014
CrossMark

To cite: Devasia $T$ Kareem H, Prasad R, et al. BMJ Case Rep Published online: [please include Day Month Year] doi:10.1136/ bcr-2014-205334

\section{DESCRIPTION}

A 65-year-old man presented with symptoms of angina at rest. On evaluation, his ECG showed T wave inversion in the anterior leads. Troponin $T$ was elevated. Echocardiography revealed that the apex and anterior wall of the left ventricle was hypokinetic with normal left ventricular function. Fluoroscopy during the angiogram revealed a stunning image of crescent-shaped extensive pericardial calcification along the right atrium and right ventricle (figure 1, video 1). An extensive crescentshaped calcification was noted (figure 2, video 2). Extension into the diaphragmatic surface was seen in the lateral view (video 3). The coronary angiogram revealed a triple vessel disease. He was evaluated for pericardial calcification. CT of the chest showed dense pericardial calcification along the right atrium, right ventricle and atrioventricular groove (figure 3 ). The patient did not give a history of having tuberculosis in the past. Echocardiography was reviewed, which showed that there was no significant respiratory variation in mitral and tricuspid inflow velocities (figures 4

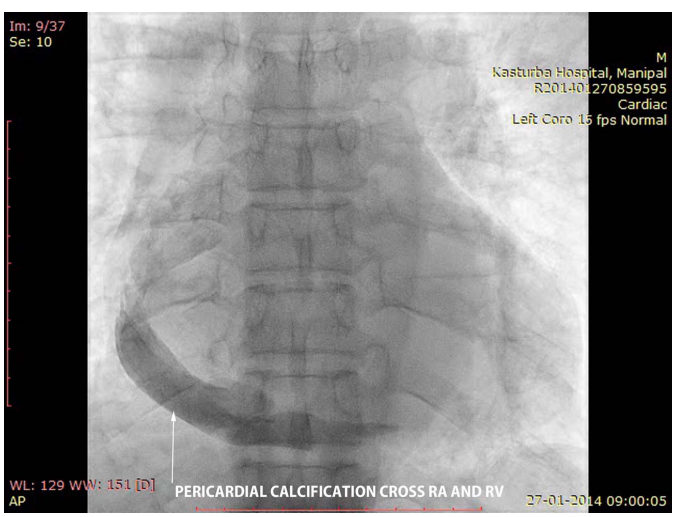

Figure 1 Anteroposterior (AP) view showing extensive calcification along the right atrium and right ventricle.

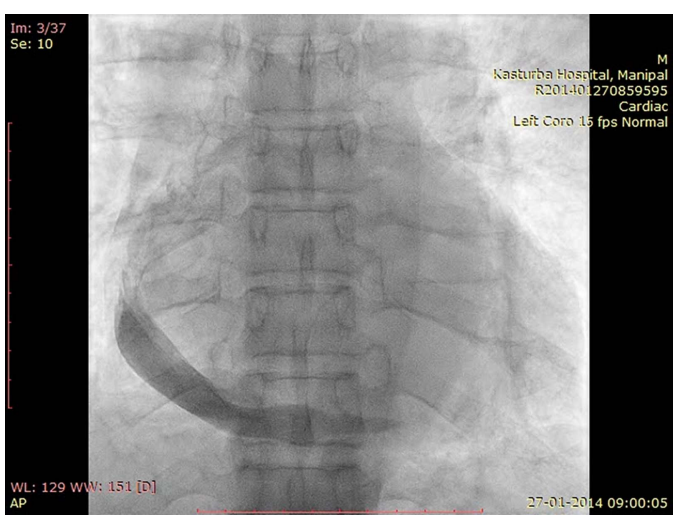

Video 1 AP view showing extensive calcification along right atrium and right ventricle. and 5). Tissue Doppler velocities were normal (figures 6 and 7). Hence, constrictive pericarditis was ruled out. There was no evidence of hypercalcaemia or parathyroid abnormality.

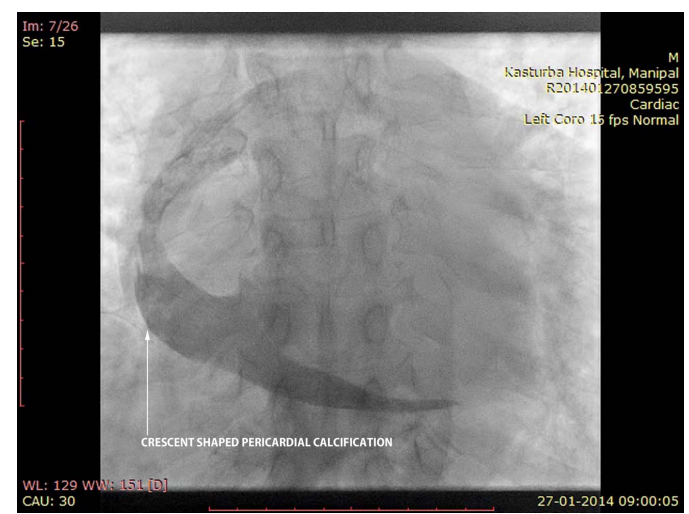

Figure 2 Anteroposterior (AP) caudal view showing crescent-shaped calcification in the pericardium.

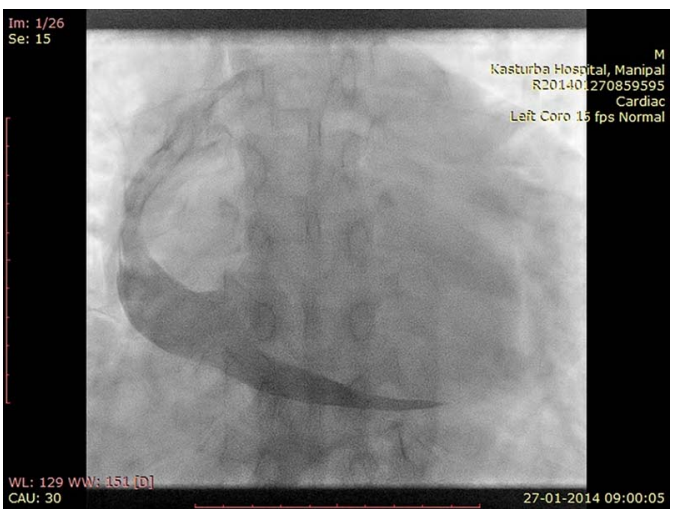

Video 2 AP Caudal view showing crescent shaped calcification in the pericardium.

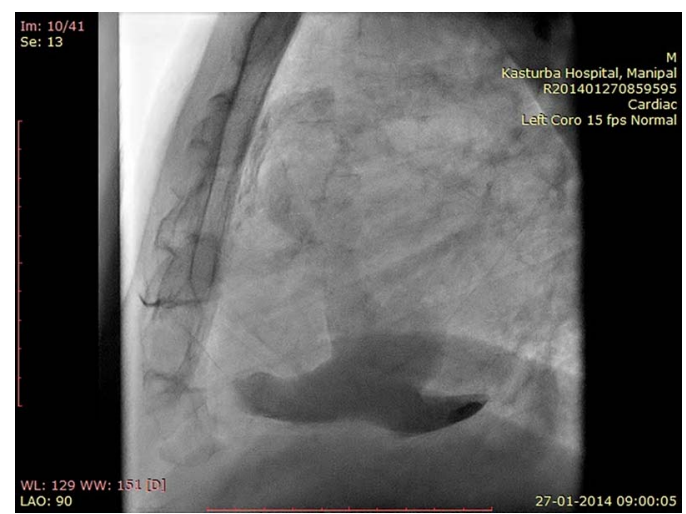

Video 3 lateral view showing extensive calcification in right atrium, right ventricle and diaphragmatic surface. 
Figure 3 CT scan showing extensive pericardial calcification along the right atrium and ventricle.
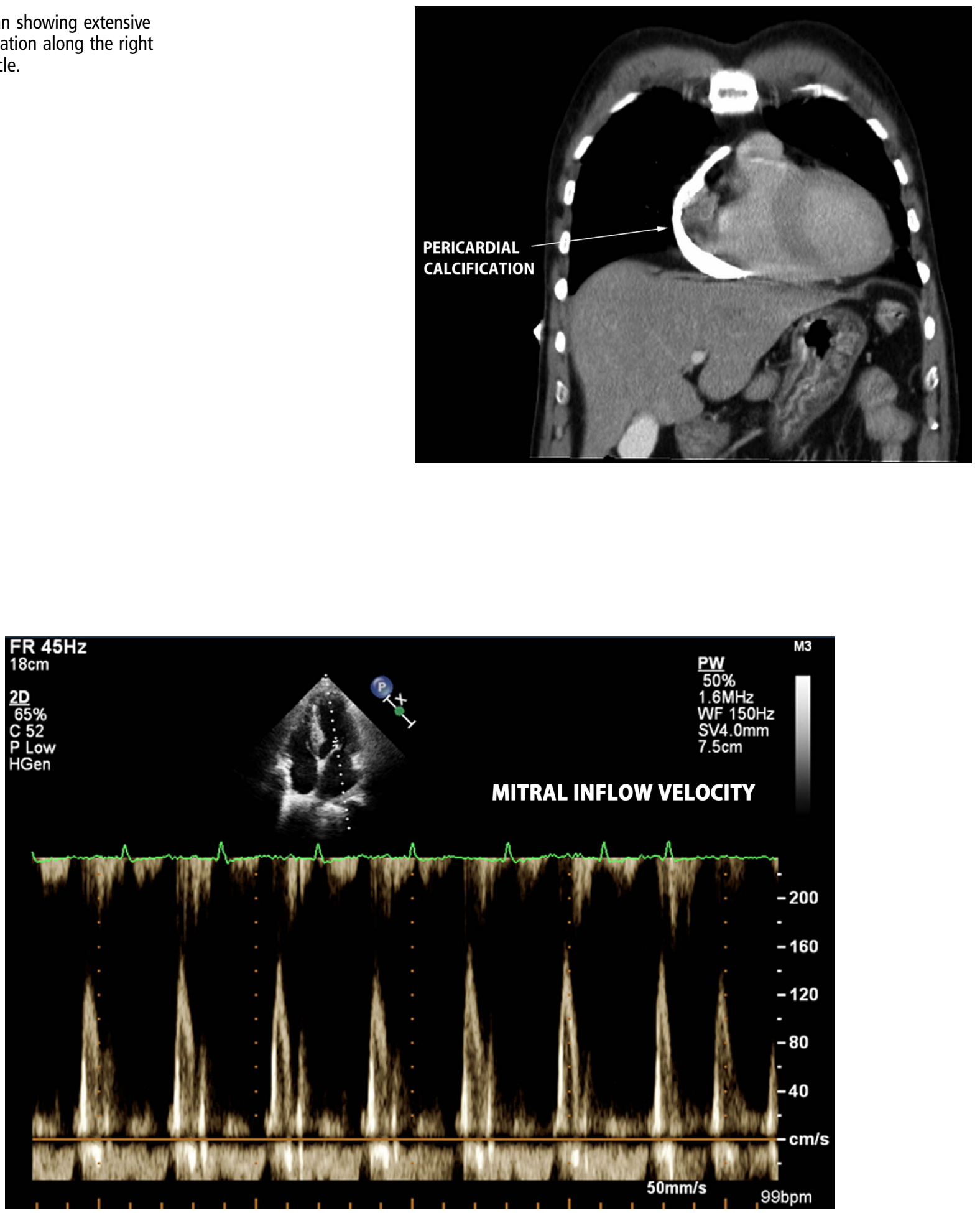

Figure 4 Echocardiography showing mitral inflow velocity with no significant respiratory inflow variation. 


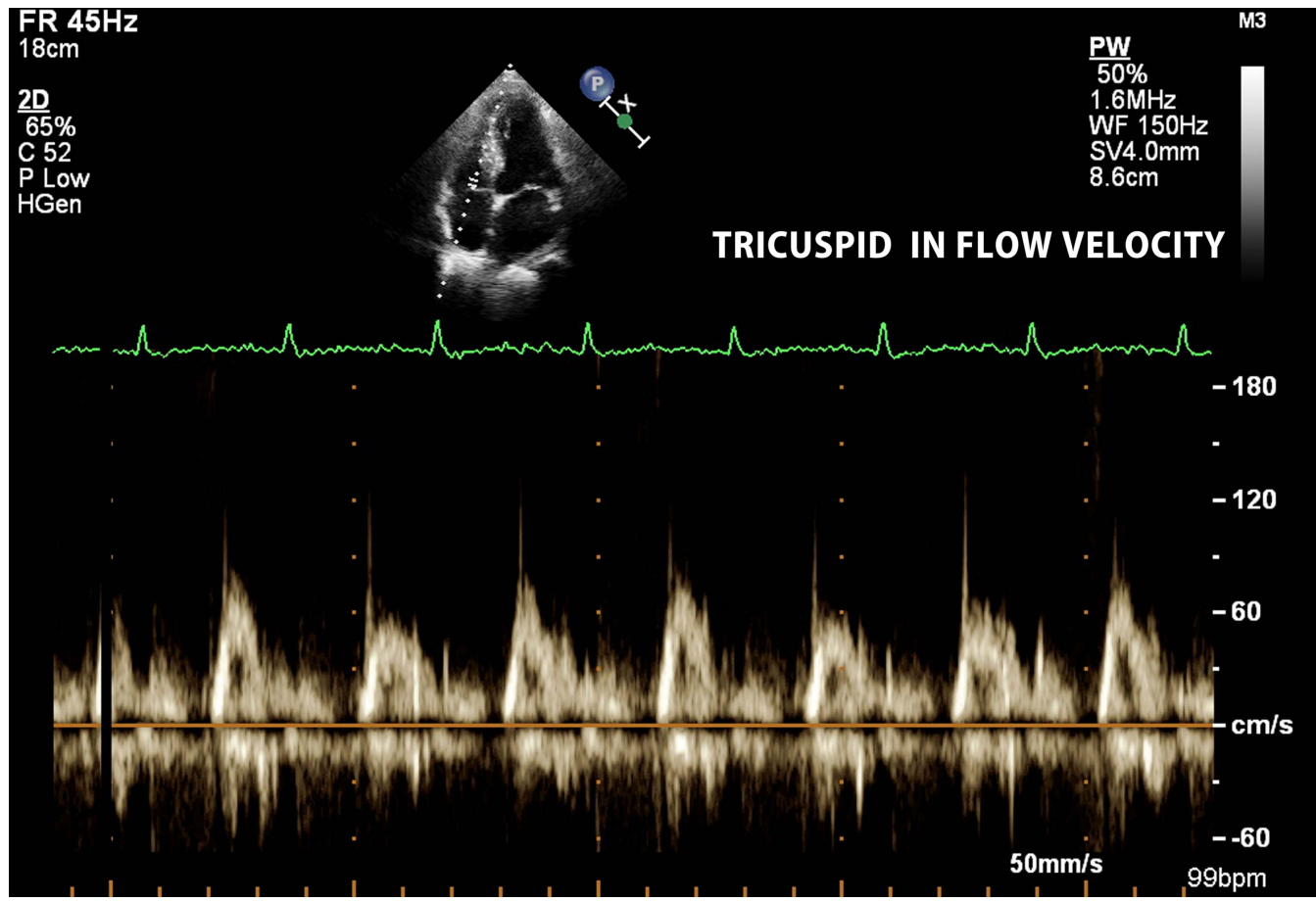

Figure 5 Echocardiography showing tricuspid inflow velocity with no significant respiratory inflow variation.

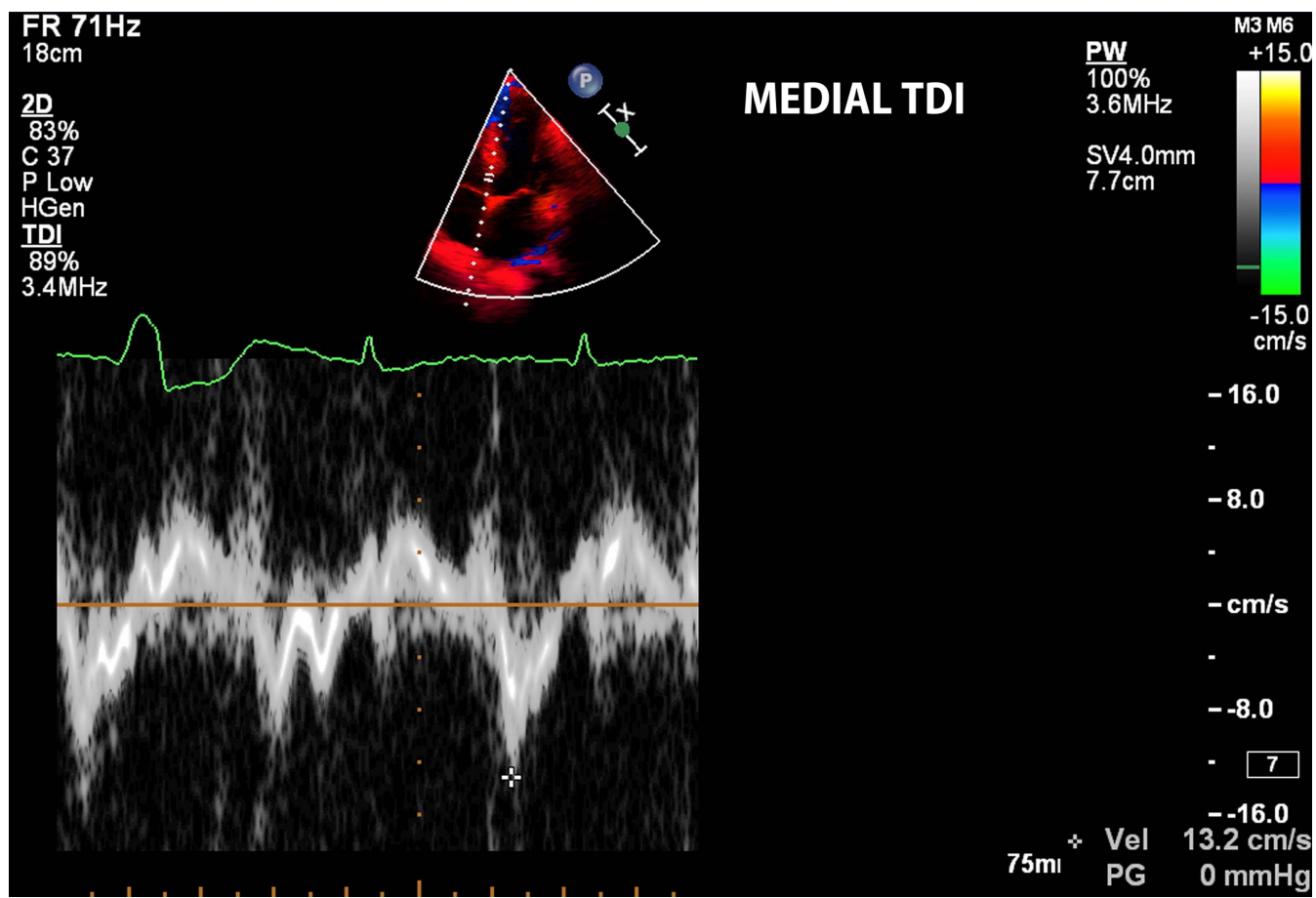

Figure 6 Tissue Doppler imaging showing normal medial annular velocities. 


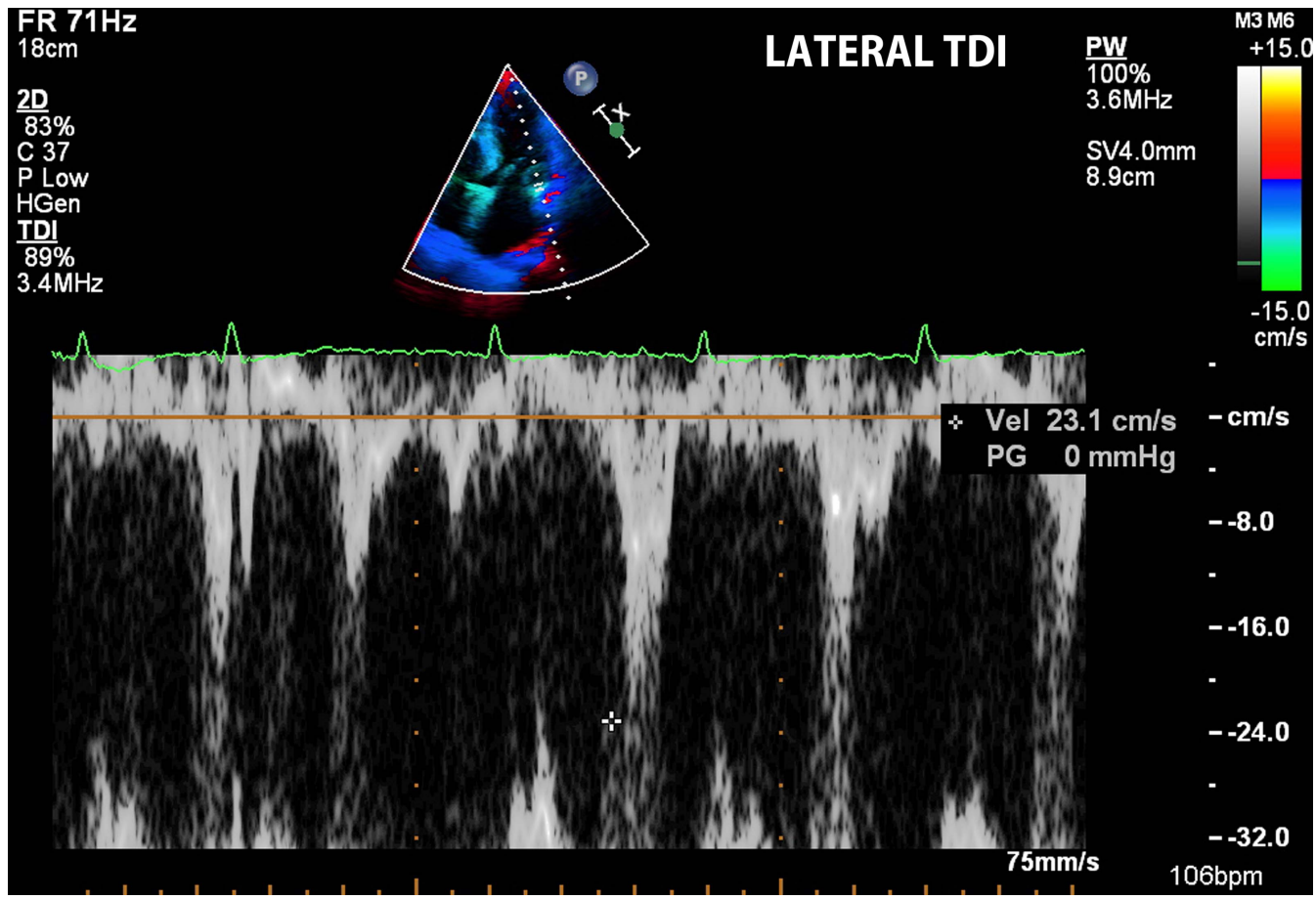

Figure 7 Tissue Doppler imaging showing normal lateral annular velocities.

The most common cause for pericardial calcification is tuberculosis. ${ }^{1}$ Whereas in the developed countries, common causes for the same is postsurgery, trauma, uraemia and postradiation and idiopathic. ${ }^{1}$ The atrioventricular groove is the most common site for pericardial calcification, along with involve-

\section{Learning points}

- Pericardial calcification may be an incidental finding on X-ray or fluoroscopy.

- The most common cause of pericardial calcification is tuberculosis.

- Extensive calcification of the pericardium may occur in the absence of constrictive pericarditis. ment of the inferior and the diaphragmatic portions of the pericardium. ${ }^{1}$ Pericardial calcification is not pathognomonic of constrictive pericarditis. ${ }^{1}$ Thirty to $70 \%$ of patients with constrictive pericarditis have pericardial calcification. ${ }^{2}$ In our patient, in spite of having an extensive pericardial calcification, there was no evidence found of constrictive pericarditis on echocardiography.

Competing interests None.

Patient consent Obtained.

Provenance and peer review Not commissioned; externally peer reviewed.

\section{REFERENCES}

1 Gowda RM, Boxt LM. Calcifications of the heart. Radiol Clin North Am 2004;42:603-17.

2 Cornell SH, Rossi NP. Roentgenographic findings in constrictive pericarditis: an analysis of 21 cases. Am J Roentgenol Radium Ther Nucl Med 1968;102:301-4.

Copyright 2014 BMJ Publishing Group. All rights reserved. For permission to reuse any of this content visit http://group.bmi.com/group/rights-licensing/permissions.

BMJ Case Report Fellows may re-use this article for personal use and teaching without any further permission.

Become a Fellow of BMJ Case Reports today and you can:

- Submit as many cases as you like

- Enjoy fast sympathetic peer review and rapid publication of accepted articles

- Access all the published articles

- Re-use any of the published material for personal use and teaching without further permission

For information on Institutional Fellowships contact consortiasales@bmjgroup.com

Visit casereports.bmj.com for more articles like this and to become a Fellow 